\title{
Ascorbic Acid Uptake and Regulation of Type I Collagen Synthesis in Cultured Vascular Smooth Muscle Cells
}

\author{
Huan Qiao Jason Bell Saul Juliao Liying Li James M. May \\ Department of Medicine, Vanderbilt University School of Medicine, Nashville, Tenn., USA
}

\section{Key Words}

Sodium-dependent vitamin C transporter - Vitamin C . Type I collagen • Western blotting • Collagen subtypes • A10 smooth muscle cells

\begin{abstract}
Background/Aims: Vascular smooth muscle cells contribute both to the structure and function of arteries, but are also involved in pathologic changes that accompany inflammatory diseases such as atherosclerosis. Since inflammation is associated with oxidant stress, we examined the uptake and cellular effects of the antioxidant vitamin ascorbic acid in cultured A10 vascular smooth muscle cells. Methods/Results: A10 cells concentrated ascorbate against a gradient in a sodium-dependent manner, most likely on the sodium-dependent vitamin C transporter type 2 (SVCT2) ascorbate transporter, which was present in immunoblots of cell extracts. Although ascorbate did not affect A10 cell proliferation, it stimulated radiolabeled proline incorporation and type I collagen synthesis. The latter was evident in the cells as increases in pro $\alpha 1(\mathrm{I})$ collagen and conversion of pro $\alpha 1$ (I) and pro $\alpha 2$ (I) collagen to mature forms that were released from the cells and deposited as extracellular matrix. Intracellular type I procollagen maturation was optimal at intracellular ascorbate concentrations of $200 \mu \mathrm{M}$ and below, which
\end{abstract}

were readily achieved by culture of the cells at plasma physiologic ascorbate concentrations. Conclusion: These results show that the SVCT2 facilitates ascorbate uptake by vascular smooth muscle cells, which in turn increases both the synthesis and maturation of type I collagen.

Copyright $\odot 2008$ S. Karger AG, Basel

\section{Introduction}

In response to acute arterial injury, such as from angioplasty/stenting or to chronic injury as a result of damage from oxidized low-density lipoprotein, cytokines and growth factors are released from damaged endothelial and macrophage foam cells $[1,2]$. These factors reach vascular smooth muscle cells (VSMCs) in the media or intima and cause them to dedifferentiate, proliferate, and migrate to form the neointima $[1,3]$. This uncontrolled proliferation of VSMCs is an important factor in the pathogenesis of atherosclerosis and of restenosis following angioplasty $[1,4]$. There is accumulating evidence that this response is mediated, at least in part, by oxidant stress in the vascular wall $[1,5]$. This opens the possibility that antioxidant therapies might ameliorate either its occurrence or its detrimental effects. For example, a role for ascorbic acid in preventing VSMC proliferation and

\section{KARGER}

๑) 2008 S. Karger AG, Basel

Fax +41613061234

E-Mail karger@karger.ch

www.karger.com www.karger.com/jvr
Dr. James M. May

Department of Medicine, Vanderbilt University School of Medicine

754 Preston Research Building

2220 Pierce Ave., Nashville, TN 37232 (USA)

Tel. +1 615936 1661, Fax +1 615936 1667, E-Mail james.may@vanderbilt.edu 
dedifferentiation is suggested by the results of a clinical trial of restenosis after angioplasty, in which subjects receiving oral ascorbate supplements had $25 \%$ larger luminal diameters and required 50\% less intervention compared to a clinically matched control population [6]. Similar results regarding maintenance of luminal diameter were observed in studies of coronary restenosis in pigs using combinations of ascorbate and $\alpha$-tocopherol $[7,8]$.

The mechanism(s) underlying the effects of ascorbate on VSMC proliferation, migration, and differentiation have not been clearly defined, but may relate to the role of the vitamin in collagen synthesis and deposition. Ascorbate enhances both the synthesis $[9,10]$ and hydroxylation of procollagen in VSMCs [11], such that without ascorbate cultured VSMCs make little collagen [12]. Indeed, although ascorbate deficiency in atherosclerosisprone mice also unable to make ascorbate does not affect aortic lesion size, the collagen content of atherosclerotic lesions is markedly decreased [13]. Whereas collagen synthesis is required for VSMC migration and proliferation $[14,15]$, the overall effect of ascorbate in these cells seems to be to decrease proliferation $[14,16]$ and enhance maturation [17-19]. The latter mechanisms could contribute to decreased neointimal smooth muscle cell accumulation seen in the above-noted in vivo studies.

Although several studies have documented that ascorbate stimulates collagen synthesis in VSMCs, none have compared either the ability of the cells to take up ascorbate or intracellular ascorbate concentrations with effects on collagen synthesis. Since it is intracellular ascorbate that stimulates type I collagen synthesis and hydroxylation in VSMCs, it is relevant to correlate intracellular ascorbate with collagen synthesis, especially with regard to the pattern of collagen subtype maturation and release. Accordingly, we evaluated ascorbate uptake and its mechanism, as well as the resulting effects of intracellular ascorbate on cell proliferation and collagen formation in the A10 cell line of VSMCs. This line was derived from the thoracic aorta of embryonic rats [20] and has been extensively used as a model of VSMCs [21]. Subsequent characterization of these cells with multiple smooth muscle cell markers showed them to be nondifferentiated neointimal VSMCs [21], and thus a good model for assessing ascorbate effects on type I collagen. The results of this study show that A10 cells take up ascorbate on the sodium-dependent vitamin C transporter type 2 (SVCT2) and that low intracellular ascorbate concentrations stimulate synthesis and maturation of type I collagen subtypes that are deposited as extracellular matrix.

\section{Materials and Methods}

\section{Materials}

Sigma/Aldrich Chemical Co. (St. Louis, Mo., USA) supplied the dehydroascorbic acid (DHA), ethyl-2,4-dihydroxybenzoic acid, N-2-hydroxyethylpiperazine- $\mathrm{N}^{\prime}$-2-ethanesulfonic acid, Lbuthionine sulfoxime, diethylmaleate, 1,3-bis(2-chloroethyl)-1nitrosourea, and sulfinpyrazone. Ethanol was used to dissolve ethyl-2,4-dihydroxybenzoic acid and dimethylsulfoxide to dissolve diethylmaleate before further dilution in Krebs-Ringer-N2-hydroxyethylpiperazine- $\mathrm{N}^{\prime}$-2-ethanesulfonic acid (KRH) buffer, such that the concentration of neither solvent was greater than $0.8 \%$ (v/v). KRH buffer consisted of $20 \mathrm{mM} \mathrm{N}$-2-hydroxyethylpiperazine-N'-2-ethanesulfonic acid, $128 \mathrm{mM} \mathrm{NaCl}, 5.2 \mathrm{mM} \mathrm{KCl}$, $1 \mathrm{mM} \mathrm{NaH}_{2} \mathrm{PO}_{4}, 1.4 \mathrm{mM} \mathrm{MgSO}_{4}$, and $1.4 \mathrm{mM} \mathrm{CaCl}_{2}, \mathrm{pH}$ 7.4. Perkin-Elmer Life and Analytical Sciences, Inc. (Boston, Mass., USA) supplied the radionuclides used.

\section{Cell Culture}

A10 cells (obtained from the American Type Culture Collection) were cultured in Dulbecco's minimal essential medium containing $10 \%(\mathrm{v} / \mathrm{v})$ heat-inactivated fetal bovine serum, which was prepared by the Cell Culture Core of the Vanderbilt Diabetes Research and Training Center. Cells were cultured to near confluence at $37^{\circ} \mathrm{C}$ in humidified air containing $5 \% \mathrm{CO}_{2}$. Just before an experiment, cells were rinsed 3 times in $2 \mathrm{ml}$ of $\mathrm{KRH}$ buffer at $37^{\circ} \mathrm{C}$.

\section{Assay of Ascorbate Transport}

Following treatments as noted, near confluent A10 cells in 12well plates were incubated at $23^{\circ} \mathrm{C}$ in $\mathrm{KRH}$ that contained $5 \mathrm{mM}$ D-glucose, $0.5 \mathrm{~mm}$ glutathione $(\mathrm{GSH})$, and $0.05 \mu \mathrm{Ci}$ of $\mathrm{L}-[1-$ $\left.{ }^{14} \mathrm{C}\right]$ ascorbic acid. The total ascorbate concentration was $6-9 \mu \mathrm{M}$, unless otherwise stated. After $30 \mathrm{~min}$ of incubation, the supernatant was aspirated, and the cells were rinsed twice in $2 \mathrm{ml}$ of icecold KRH. The cell monolayer was treated with $1 \mathrm{ml}$ of $0.05 \mathrm{~N}$ $\mathrm{NaOH}$, the cells were scraped from the plate, and the combined extract was added to $5 \mathrm{ml}$ of Ecolume liquid scintillation fluid (ICN, Costa Mesa, Calif., USA) and mixed. The radioactivity of duplicate samples was measured in a Packard CA-2200 liquid scintillation counter, after allowing at least $1 \mathrm{~h}$ for decay of chemiluminescence.

\section{Assay of Ascorbate and GSH}

Following culture and incubations as indicated in 6-well plates, the medium was aspirated, and the adherent cells were gently rinsed twice with $2 \mathrm{ml}$ of ice-cold $\mathrm{KRH}$. The last rinse was removed and the cell monolayer was treated with $0.1 \mathrm{ml}$ of $25 \%$ metaphosphoric acid (w/v) for several minutes, followed by partial neutralization with $0.35 \mathrm{ml}$ of a buffer containing $0.1 \mathrm{M}$ $\mathrm{Na}_{2} \mathrm{HPO}_{4}$ and $0.05 \mathrm{~mm}$ EDTA, pH 8.0. Adherent material was scraped from the plate, and the lysate was removed and centrifuged at $3^{\circ} \mathrm{C}$ for $1 \mathrm{~min}$ at $13,000 \mathrm{~g}$. Duplicate aliquots of the supernatant were taken for assay of ascorbic acid by high-performance liquid chromatography as previously described [22], except that ascorbate was detected by its ultraviolet absorption at a wavelength of $260 \mathrm{~nm}$ on a Waters Model 2487 spectrophotometer. In some experiments, ascorbate was also measured in $0.1 \mathrm{ml}$ of the incubation medium by adding $0.1 \mathrm{ml}$ of $25 \%$ metaphosphoric acid (w/v), mixing, neutralizing with $0.35 \mathrm{ml}$ of the above 
phosphate/EDTA buffer, and centrifuging to remove precipitated solids before assay of ascorbate. GSH was assayed in duplicate by the method of Hissin and Hilf [23]. Intracellular concentrations of ascorbate and GSH were calculated based on the intracellular distribution space of 3-O-methylglucose in A10 cells and normalized to measured protein in an experiment. This was measured as described previously for endothelial cells in culture [24] and was $3.7 \pm 0.6 \mu \mathrm{l} / \mathrm{mg}$ protein $(\mathrm{n}=24$, mean $\pm \mathrm{SD})$.

\section{Assays of Cell Proliferation}

Cellular uptake of $\left[{ }^{3} \mathrm{H}\right]$ thymidine was measured as described by Totzke et al. [25], with minor modifications. Subconfluent cultures (70-90\%) of A10 cells in 24-well plates were washed and then incubated in cultured medium containing $0.2 \%$ fetal bovine serum and glutamine for $24 \mathrm{~h}$ to growth arrest cells. Ascorbate $(0-300 \mu \mathrm{M})$ was then added for $24 \mathrm{~h}$ and $\left[{ }^{3} \mathrm{H}\right]$ thymidine $(1 \mu \mathrm{Ci} /$ well) for the final $16 \mathrm{~h}$ of the incubation. After this, the supernatant was aspirated and cells were rinsed twice with phosphatebuffered saline (12.5 mM sodium phosphate, $140 \mathrm{mM} \mathrm{NaCl}, \mathrm{pH}$ 7.4) before being fixed with methanol (100\%)/glacial acetic acid (3:1) for at least $1 \mathrm{~h}$ at room temperature. Two further rinses with methanol/water (4:1) were performed before lysing cells with $1 \mathrm{ml}$ of $1 \mathrm{M} \mathrm{NaOH}$ and scintillation counting.

Incorporation of 5-bromo-2-deoxyuridine into synchronized A10 cells pretreated with $0-300 \mu \mathrm{M}$ ascorbate was measured as described by Meyer et al. [26]. Cells grown on eight-chamber slides were stained using mouse monoclonal antibodies to 5-bromo-2-deoxyuridine (Ab-2, 1:100; Oncogene Science, San Diego, Calif., USA). Before staining for incorporated 5-bromo-2-deoxyuridine, DNA was partially denatured with $2 \mathrm{~N} \mathrm{HCl}$ for $30 \mathrm{~min}$. As a control for specific staining, cells were also incubated with assay buffer but the primary antibody was omitted. To stain for 5-bromo-2-deoxyuridine, cells were serially stained and bound biotinylated anti-5-bromo-2-deoxyuridine antibody (Ab-3; Oncogene Science) was visualized using 3,3'-diaminobenzidine (brown color) as a peroxidase substrate.

\section{Assay of Proline Uptake and Incorporation}

A10 cells at near confluence in culture were treated with $1 \mu \mathrm{Ci}$ of $\left[2,3-{ }^{3} \mathrm{H}\right]$ proline and cultured for an additional $3 \mathrm{~h}$ at $37^{\circ} \mathrm{C}$, following which they were rinsed 3 times in $\mathrm{KRH}$ and prepared for radioactive counting as described for the assay of ascorbate.

\section{Polyacrylamide Gel Electrophoresis and Immunoblotting of}

SVCTs and Type I Collagen

Cells cultured in T-25 flasks were rinsed once in phosphatebuffered saline, and solubilized in a lysis buffer consisting of 150 $\mathrm{mm} \mathrm{NaCl}, 1 \%$ Nonidet $\mathrm{P} 40$ (v/v), $0.5 \%$ sodium deoxycholate (w/v), and $0.1 \%$ sodium lauryl sulfate $(\mathrm{w} / \mathrm{v})$. To prevent proteolysis, this buffer also contained $0.1 \mathrm{mg} / \mathrm{ml}$ phenylmethylsulfonyl fluoride, and leupeptin, pepstatin and aprotinin, each at $0.01 \mathrm{mg} / \mathrm{ml}$. After mixing, the lysate was stored on ice for $30 \mathrm{~min}$. The lysate was combined with an equal volume of sample buffer, which consisted of $125 \mathrm{~mm}$ Tris- $\mathrm{HCl}, 20 \%$ (v/v) glycerol, $4 \%$ (w/v) sodium lauryl sulfate, $10 \%(\mathrm{v} / \mathrm{v})$ mercaptoethanol, and $0.0025 \%$ bromphenol blue (w/v), pH 6.8. Samples were centrifuged for $10 \mathrm{~s}$ at $13,000 \mathrm{~g}$, and $20-30 \mu$ g protein of solubilized material was subjected to 5 and $10 \%$ sodium dodecyl sulfate polyacrylamide gel electrophoresis for type I collagen and SVCT2, respectively, according to the method of Laemmli [27]. Electrophoresis and transfer to poly(vinylidine difluoride) membrane were performed as previously described [28]. The SVCT2 was probed with a 1:200 dilution of an affinity-purified rabbit polyclonal antibody that was specific for the SVCT2 transporter (No. SVCT21-A, Alpha Diagnostic International, San Antonio, Tex., USA). The sodium-dependent vitamin C transporter type 1 (SVCT1) was probed with the same dilutions of two different affinity-purified goat polyclonal antibodies made to different portions of the SVCT1 sequence (sc9924 and sc-30113, Santa Cruz Biotechnology, Inc., Santa Cruz, Calif., USA). Type I collagen was detected using 1:8,000 dilutions of affinity-purified polyclonal rabbit antibodies against rat type I collagen. One antibody (SC-8784-R, Santa Cruz Biotechnology) was specific for full-length pro $\alpha 1$ (I) collagen and the mature $\alpha 1$ (I) collagen lacking both terminal propeptides. A second antibody (ab34710, Abcam, Inc., Cambridge, Mass., USA) detected collagen of both the $1 \alpha$ and $2 \alpha$ subtypes. Actin served as a control for the amount of sample loaded and was detected in immunoblots using an antibody to actin at a dilution of 1:200 (SC-1616-R, Santa Cruz Biochemicals). The secondary antibody for all immunoblots was anti-rabbit IgG conjugated to horseradish peroxidase (No. A0545, Sigma-Aldrich, Inc., St. Louis, Mo., USA) and was used at a 1:5,000 dilution. Membranes were blocked with 5\% (w/v) nonfat dry milk at $23^{\circ} \mathrm{C}$ for $1 \mathrm{~h}$, rinsed in phosphate-buffered saline containing $1 \%$ Tween 20 , and sequentially incubated with both primary and secondary antibodies overnight at $4^{\circ} \mathrm{C}$. Bands were stained using ECL Plus Western blotting reagents (RPN 2132, Amersham Biosciences, Piscataway, N.J., USA). Band locations were determined using prestained molecular weight markers. Immunoblotting results were confirmed at least 3 times.

\section{Immunofluorescence Microscopy for Type I Collagen}

A10 cells were seeded onto multiwell slides and cultured for $24 \mathrm{~h}$, after which the medium was replaced with fresh medium containing either 0 or $50 \mu \mathrm{M}$ sodium ascorbate. Cells were maintained under these conditions for 6 days with daily addition of ascorbate. The cells were rinsed free of medium with phosphate-buffered saline, fixed in cold acetone, blocked for $30 \mathrm{~min}$ at $23^{\circ} \mathrm{C}$ with $1 \mathrm{mg} / \mathrm{ml}$ bovine serum albumin plus $0.3 \%$ Triton X-100 or with bovine serum albumin alone, followed by incubation at $23^{\circ} \mathrm{C}$ for $2 \mathrm{~h}$ with rabbit antiserum to type I collagen (ab34710). The bound primary antibody was detected with Cy2-conjugated goat anti-rabbit IgG (1:400 dilution) at $23^{\circ} \mathrm{C}$ for $1 \mathrm{~h}$. After 3 rinses in phosphate-buffered saline, cells were treated with glycerol/phosphate-buffered saline (9:1, vol/vol) and evaluated by fluorescence microscopy.

\section{Data Analysis}

Results are shown as mean + standard error. Statistical comparisons were made using SigmaStat 2.0 software (Jandel Scientific, San Rafael, Calif., USA). Differences between treatments were assessed by one-way analysis of variance with post hoc testing using Dunnett's test.

\section{Results}

A10 cells contained little or no ascorbate in culture (fig. 1a, zero time). However, cells incubated with $0.2 \mathrm{mM}$ ascorbate progressively took up the vitamin over $2 \mathrm{~h}$, 


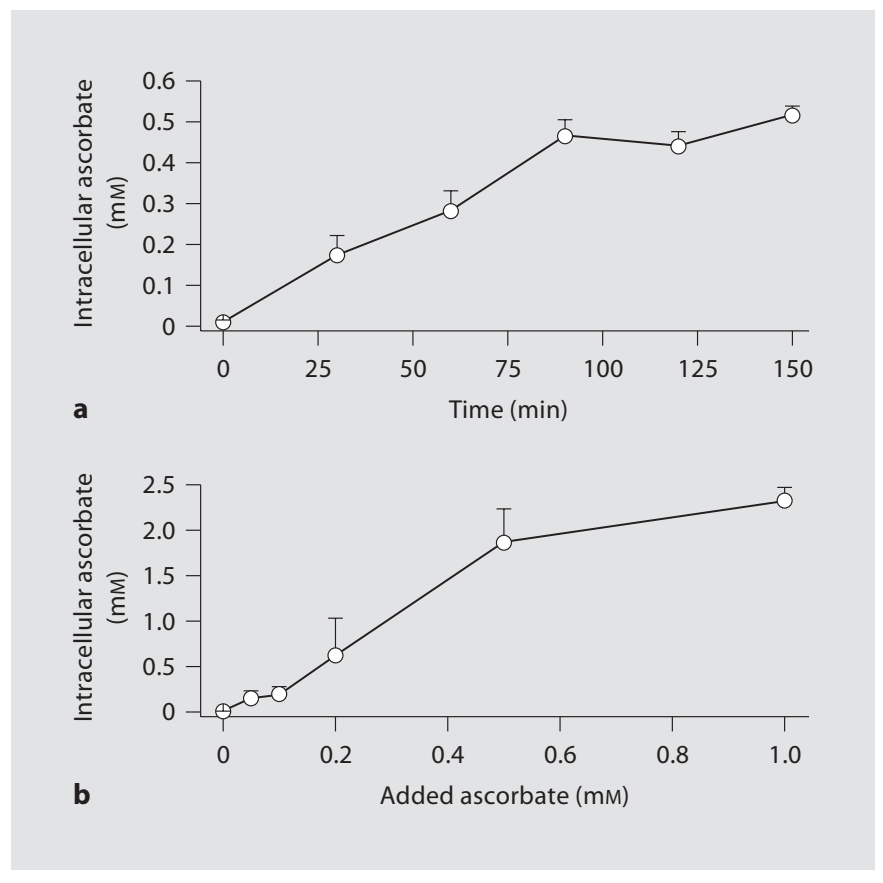

Fig. 1. A10 cells take up and accumulate ascorbate in culture. a Near confluent A10 cells were treated with $0.2 \mathrm{mM}$ ascorbate in culture medium for the times indicated followed by 3 rinses of the cells in $\mathrm{KRH}$ and assay of their ascorbate content. b Cells were treated at $37^{\circ} \mathrm{C}$ with the indicated concentrations of ascorbate in culture medium. After $16-18 \mathrm{~h}$ in culture for ascorbate-treated cells, medium was removed and the cells were rinsed 3 times in $\mathrm{KRH}$ and taken for assay of intracellular ascorbate. Results are shown from 4 experiments. reaching intracellular concentrations as high as $0.5 \mathrm{mM}$ (fig. 1a). Incubation of cells with increasing amounts of ascorbate for $16-18 \mathrm{~h}$ resulted in intracellular ascorbate concentrations that rose to 2-3 $\mathrm{mm}$ (fig. 1b). During such overnight loading, intracellular ascorbate was typically twice the initial loading concentration. Further, at the end of the incubations, extracellular ascorbate concentrations were less than $5 \%$ of those added initially (results not shown). Together, these results indicate that A10 cells take up and retain ascorbate against a concentration gradient.

To determine the mechanism by which A10 cells take up ascorbate, specific ascorbate transport was measured over $30 \mathrm{~min}$. This time for sampling was chosen since uptakes of both unlabeled (fig. 1a) and radiolabeled ascorbate (results not shown) were also linear for $1 \mathrm{~h}$. As shown in figure $2 \mathrm{a}$, uptake of radiolabeled ascorbate was inhibited $50 \%$ by competition with $1 \mathrm{~mm}$ unlabeled ascorbate, $45 \%$ by omission of sodium from the incubation medium, and $67 \%$ by the organic anion transport inhibitor sulfinpyrazone. Ascorbate transport was not inhibited by either $25 \mu \mathrm{M}$ cytochalasin B or by $40 \mathrm{~mm}$ 3-O-methylglucose. Both are known inhibitors of glucose transport. As depicted in figure $2 \mathrm{~b}$, the SVCT2 protein was detected on immunoblots in A10 cells as bands in the $74-$ to $76-\mathrm{kDa}$ range. The SVCT1 was not detected with either of two SVCT1 antibodies (results not shown). Together, these results show that ascorbate enters the cell via a transporter
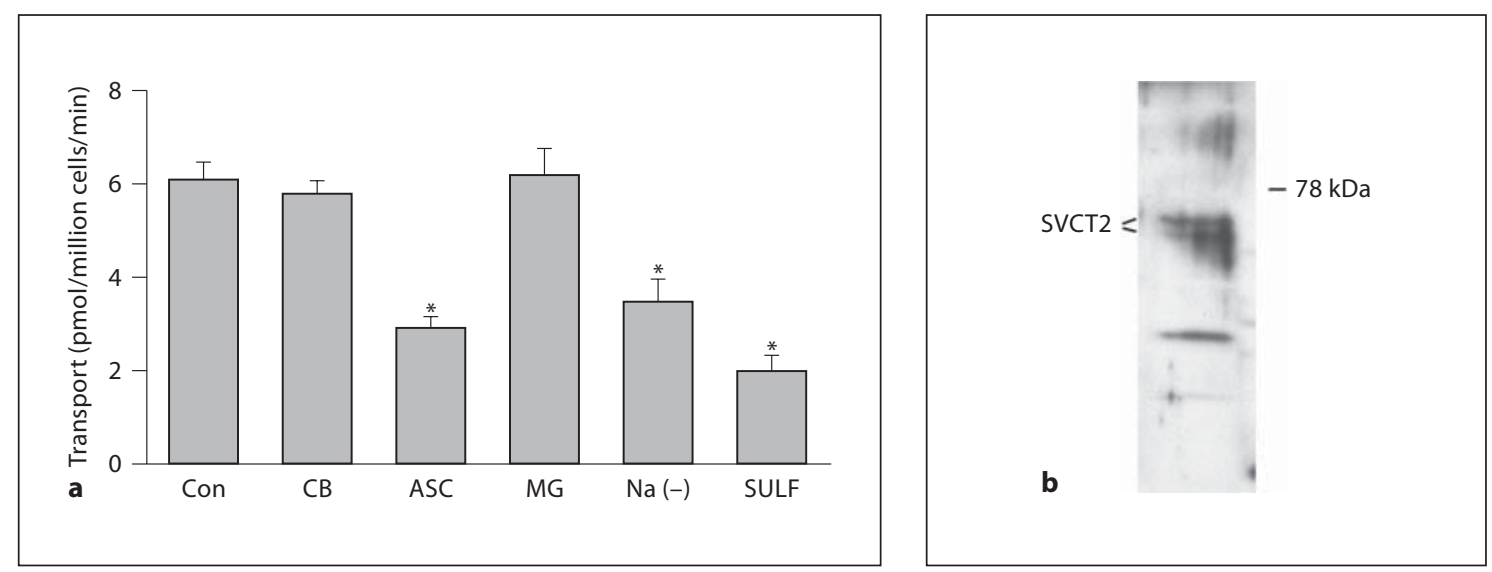

Fig. 2. A10 cells transport ascorbate by both the SVCT1 and SVCT2. a Rinsed cells were incubated in KRH at $23^{\circ} \mathrm{C}$ in the presence of $5 \mathrm{mM}$ D-glucose, $0.5 \mathrm{mM} \mathrm{GSH}$, and $0.05 \mu \mathrm{Ci}$ of $\left[1-{ }^{14} \mathrm{C}\right]$ ascorbate in the absence of further treatments (Con), or in the presence of $25 \mu \mathrm{M}$ cytochalasin B (CB), $1 \mathrm{~mm}$ ascorbate (ASC), $40 \mathrm{~mm}$ 3-o-methylglucose (MG), KRH in which sodium chloride was replaced with $140 \mathrm{mM}$ choline chloride (Na (-)), or $1 \mathrm{mM}$ sulfinpyrazone (SULF). After $30 \mathrm{~min}$, the cells were rinsed 3 times in $\mathrm{KRH}$ and taken for assay of ascorbate transport. Results are shown from 4 experiments with ${ }^{*} \mathrm{p}<0.05$ compared to the control sample. b Immunoblotting of the SVCT2 transporter. 
with features of the SVCT2 transporter, and not on the glucose transporter.

Specific ascorbate transport is known to be sensitive to the thiol-dependent redox state of the cell [29], and this was tested for A10 cells. As shown in figure 3, preincubation of A10 cells with L-buthionine sulfoximine modestly decreased ascorbate transport, whereas 1,3-bis(2-chloroethyl)-1-nitrosourea and diethylmaleate had no effect. In contrast, these agents all significantly depleted GSH. Ascorbate transport in A10 cells did not correlate well with GSH depletion by these reagents.

To determine if intracellular ascorbate affects A10 cell proliferation, incorporation of both $\left[{ }^{3} \mathrm{H}\right]$ thymidine and 5-bromo-2-deoxyuridine was measured with increasing concentrations of ascorbate under the conditions noted in figure $1 \mathrm{~b}$, except that the time in culture was $24-48 \mathrm{~h}$ before assay. There was no effect of ascorbate in either of these assays (results not shown). However, ascorbate at initial concentrations as low as $30 \mu \mathrm{M}$ did enhance cellular uptake and incorporation of $\mathrm{L}-2,3-\left[{ }^{3} \mathrm{H}\right]$ proline into A 10 cells by about $40 \%$ over $72 \mathrm{~h}$ (fig. 4 ). Since proline will be incorporated into proteins other than collagen, to further assess effects of ascorbate on collagen synthesis by A10 cells, type I collagen was measured in cell extracts by Western blotting.

Immunoblots with an antibody specific for the $\alpha 1$ (I) collagen showed that subconfluent A10 cells contained little of $\alpha 1$ (I) collagen after initial plating (fig. 5, top panel). With time in culture, however, they generated increasing amounts of both pro $\alpha 1$ (I) collagen and mature $\alpha 1$ (I) collagen. Initially, ascorbate had little effect, but after 3 days in culture, daily additions of $100 \mu \mathrm{M}$ ascorbate increased conversion of pro $\alpha 1$ (I) collagen to mature $\alpha 1$ (I) collagen. Three days of culture with ascorbate decreased the cell content of pro $\alpha 1(\mathrm{I})$ collagen in this experiment. Evaluation of $\alpha 2$ (I) collagen was complicated in that the antibody to the $\alpha 2$ (I) subtype recognized both the $\alpha 1$ (I) and the $\alpha 2$ (I) subtypes. As shown in the middle panel of figure 5 , as with pro $\alpha 1$ (I) collagen, an increase in pro $\alpha 2$ (I) collagen with time in culture was evident, but there was overlap of bands for the mature $\alpha 1$ (I) and pro $\alpha 2$ (I) collagen at about $150 \mathrm{kDa}$. The intensity of this overlapping band was decreased by ascorbate. However, a band corresponding to mature $\alpha 2$ (I) collagen was progressively induced by culture with $100 \mu \mathrm{M}$ ascorbate. Together, these results show that the effect of ascorbate was to convert both pro $\alpha 1$ (I) and pro $\alpha 2$ (I) collagen into the mature forms for secretion into the medium. The lower panel of figure 5 shows that despite different cell densities with different times in culture, the amounts of cell material

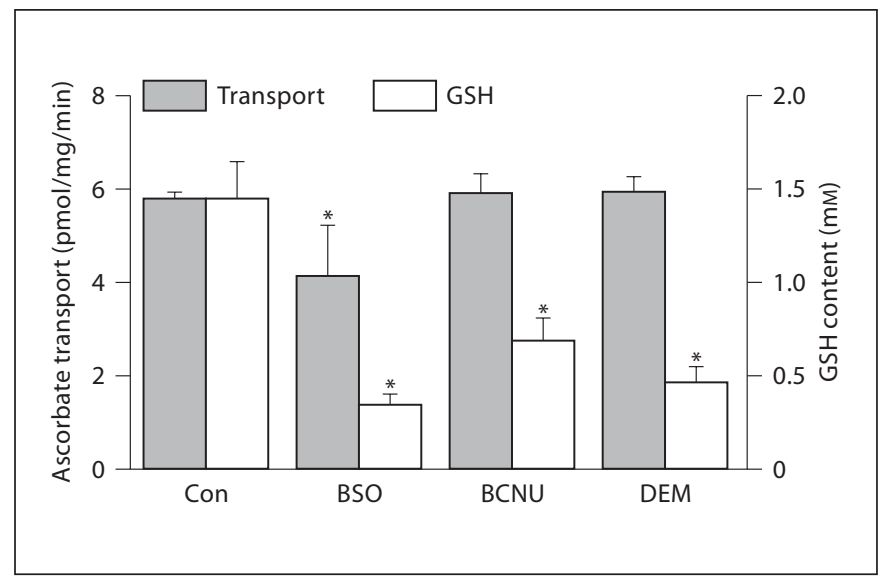

Fig. 3. Ascorbate transport does not correlate with GSH content of A10 cells. Cells were cultured overnight without or with $0.5 \mathrm{mM}$ L-buthionine sulfoximine (BSO), as indicated. Cells were then rinsed and incubated for $30 \mathrm{~min}$ at $23^{\circ} \mathrm{C}$ in $\mathrm{KRH}$ that contained $5 \mathrm{mM}$ D-glucose and no additions (Con and BSO), or either 0.5 $\mathrm{mM}$ 1,3-bis(2-chloroethyl)-1-nitrosourea (BCNU) or $1 \mathrm{mM}$ diethylmaleate (DEM). Assays of ascorbate transport and intracellular GSH were then carried out on separate batches of cells. Results were normalized to the transport activity or GSH content of cells not treated with an agent in the same assay. Results are shown for at least 4 experiments using each agent with ${ }^{*} \mathrm{p}<0.05$ compared to the respective control.

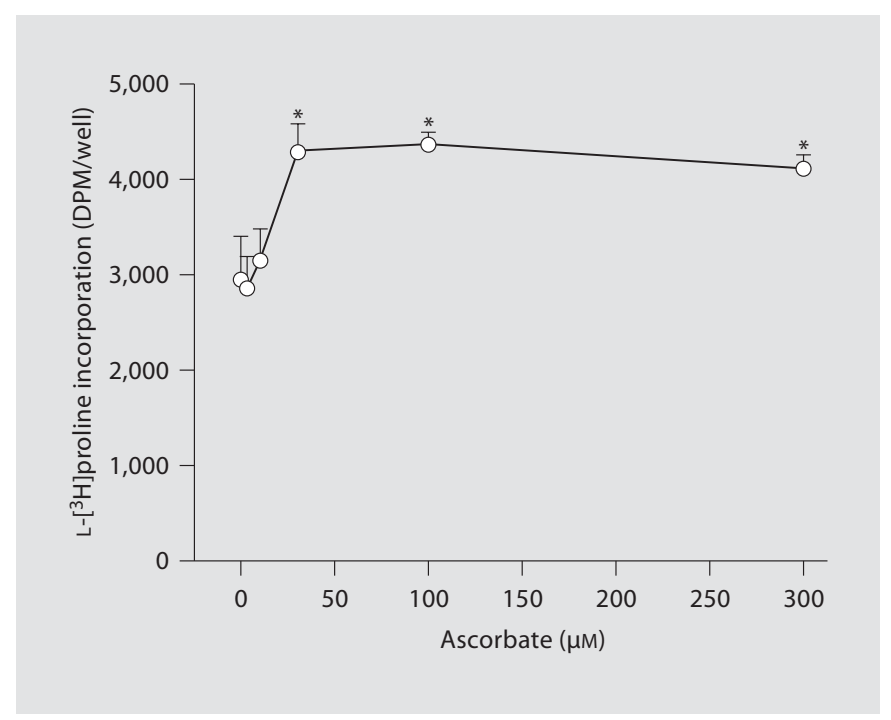

Fig. 4. Ascorbate stimulates proline incorporation into A10 cells. Subconfluent A10 cells were cultured with the indicated ascorbate concentrations added every 24 for $72 \mathrm{~h}$, followed by assay of the cell content of radioactivity. Results are shown from 3 experiments with ${ }^{*} \mathrm{p}<0.05$ compared to cells not treated with ascorbate. 


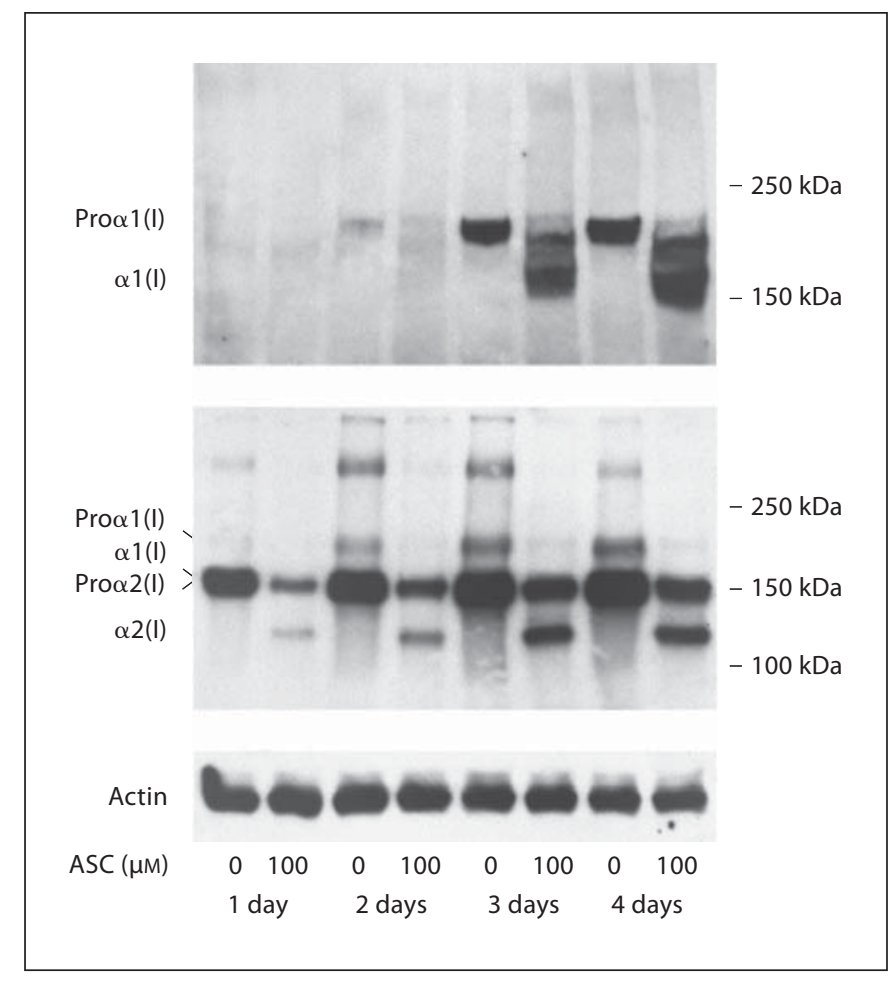

Fig. 5. Ascorbate stimulates type I collagen generation in A10 cells as measured by immunoblotting. A10 cells were cultured for up to 4 days in the absence or presence of ascorbate as noted, before 3 rinses with KRH and removal for SDS gel electrophoresis. The top panel shows results with an antibody specific for $\alpha 1$ (I) collagen, the middle panel shows results with an antibody cross-reactive with both $\alpha 1(\mathrm{I})$ and $\alpha 2(\mathrm{I})$ collagen, and the bottom panel shows the corresponding immunoblots of cell actin, which was used to assess gel protein loading. Locations of molecular weight markers are shown on the right of the immunoblot.

loaded onto the gels were similar, based on staining for actin. The effect of ascorbate to increase pro $\alpha 1$ (I) synthesis and the maturation of both $\alpha 1(\mathrm{I})$ and $\alpha 2$ (I) collagen was reversed within 1-2 days after removal of ascorbate from the medium (fig. 6). Decreases in the cell content of mature $\alpha 1(\mathrm{I})$ and $\alpha 2$ (I) collagen were associated with an increase in pro $\alpha 2$ (I) but not pro $\alpha 1$ (I) collagen in the cells (fig. 6). To determine the specificity of the effect of ascorbate on increased generation of the mature subtypes of type I collagen, cells were treated with the prolyl hydroxylase inhibitor ethyl-2,4-dihydroxybenzoic acid for 2 days during ascorbate treatment. As shown in figure 7, generation of both collagen subtypes was inhibited by ethyl-2,4dihydroxybenzoic acid, but cell accumulation of the mature $\alpha 1$ (I) collagen (top panel) was not completely inhibited by ethyl-2,4-dihydroxybenzoic acid, whereas mature

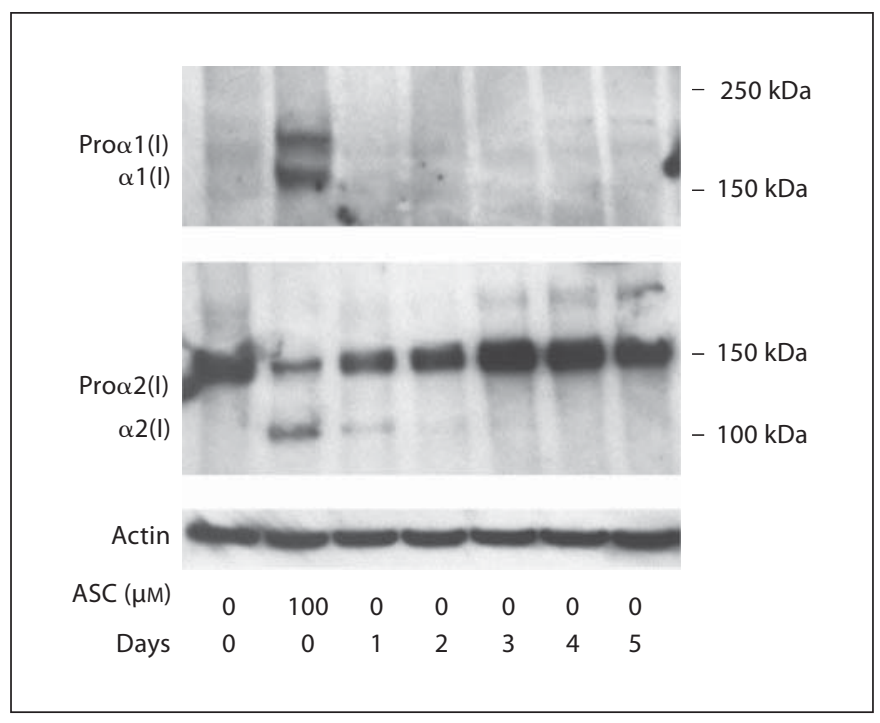

Fig. 6. Removal of ascorbate (ASC) decreases type I collagen generation in A10 cells. A10 cells were cultured for 3 days without or with daily additions of $100 \mu \mathrm{M}$ ascorbate (' 0 days'), then rinsed in culture medium and ascorbate-treated cells were cultured for the number of days indicated before rinsing, cell lysis, and immunoblotting for the content of $\alpha 1$ (I) collagen (top panel), for both $\alpha 1$ (I) and $\alpha 2$ (I) collagen (middle panel), and for actin (bottom panel). Actin staining was used to assess gel protein loading.

$\alpha 2$ (I) collagen was completely suppressed by $250 \mu \mathrm{M}$ ethyl-2,4-dihydroxybenzoic acid (bottom panel).

To determine the minimum concentration of ascorbate effective for maturation of type I collagen subunits, we carried out ascorbate concentration-response studies on cells cultured for 3 days, with the results shown in figure 8. As shown in the top panel, cell contents of both pro $\alpha 1$ (I) collagen and mature $\alpha 1$ (I) collagen increased to nearly a maximal level at about $25 \mu \mathrm{M}$ ascorbate. In contrast, intracellular levels of the mature $\alpha 2$ (I) collagen were maximally increased by ascorbate concentrations as low as $5 \mu \mathrm{M}$.

Ascorbate increased both intracellular and extracellular type I collagen in A10 cells, as detected by immunofluorescence using the antibody that cross-reacts with both the $\alpha 1$ (I) and $\alpha 2$ (I) subunits (fig. 9). In cells cultured for 6 days and permeabilized with Triton X-100, intracellular type I collagen staining was enhanced by ascorbate (fig. 9a). Cultures not permeabilized showed a marked increase in extracellular sheets of collagen in response to ascorbate (fig. 9b), as expected if ascorbate accelerated generation and export of mature $\alpha 1(\mathrm{I})$ and $\alpha 2$ (I) subunits, which subsequently deposited as fibrils around and under the cells. 


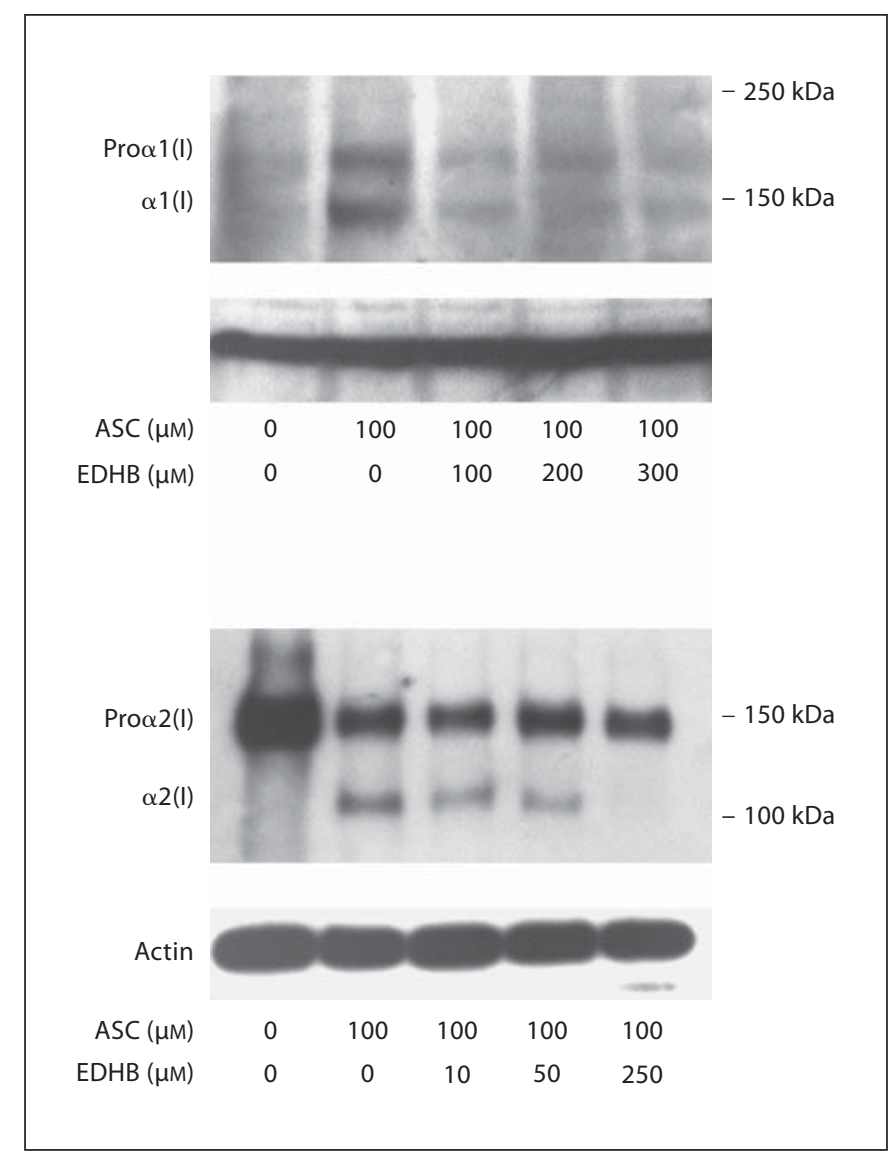

Fig. 7. Ethyl-2,4-dihydroxybenzoic acid (EDHB) inhibits ascorbate-stimulated type I collagen synthesis in A10 cells. A10 cells that had been cultured for 2 days in the absence or presence of daily additions of $100 \mu \mathrm{M}$ ascorbate were also treated with the indicated concentrations of ethyl-2,4-dihydroxybenzoic acid before cell removal for immunoblotting for the content of $\alpha 1$ (I) collagen (top panel), both $\alpha 1$ (I) and $\alpha 2$ (I) collagen (middle panel), and for actin (bottom panel). Actin staining was used to assess gel protein loading.

\section{Discussion}

Ascorbate was taken up by A10 VSMCs on what is very likely the SVCT2 ascorbate transporter, since the SVCT1 was not detected by immunoblotting. Specificity for this transporter was evident in that uptake of unlabeled and radiolabeled ascorbate was concentrative and inhibited by (1) ascorbate itself, (2) removal of sodium from the medium, and (3) the organic anion transport inhibitor sulfinpyrazone. Similar results were also observed by Holmes et al. [30] in cultured pig coronary artery smooth muscle cells, suggesting a common transport mechanism in smooth muscle cells. Another mech-

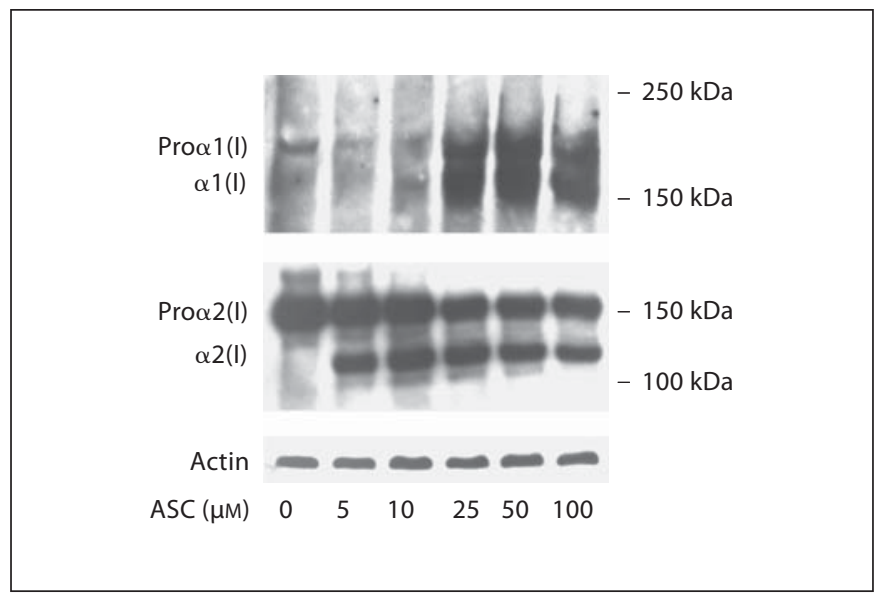

Fig. 8. Stimulation of A10 cell type I collagen generation by ascorbate (ASC) is concentration-dependent. A10 cells were cultured for 3 days with daily additions of the indicated ascorbate concentration before rinsing and removal for immunoblotting for the content of $\alpha 1$ (I) collagen (top panel), both $\alpha 1$ (I) and $\alpha 2$ (I) collagen (middle panel), and for actin (bottom panel). Actin staining was used to assess gel protein loading.

anism of ascorbate accumulation against a concentration gradient is uptake of DHA on the GLUT-type glucose transporter and intracellular reduction to ascorbate, which is then trapped in the cell due to its negative charge at physiologic $\mathrm{pH}$. Voskoboinik et al. [31] showed in human umbilical vein smooth muscle cells that initial rates of DHA uptake and reduction were comparable to those of ascorbate and that the glucose transport inhibitor phloretin prevented uptake of both DHA and ascorbate. This led them to conclude a vital role for DHA uptake on glucose transporters in supplying intracellular ascorbate to smooth muscle cells. However, phloretin is also known to inhibit ascorbate transport in Xenopus oocytes that had been injected with mRNA for the SVCT2 [32]. Additionally, in the present studies ascorbate transport was not inhibited by either cytochalasin B or 3-O-methylglucose. These are known inhibitors of the GLUT-type glucose transporters [33], so the results observed are not due to uptake of DHA on glucose transporters. Cytochalasin B was also shown not to inhibit ascorbate uptake by pig coronary smooth muscle cells [30]. Although A10 cell ascorbate transport was not as sensitive to reduced GSH depletion by thiol reagents as that of cultured endothelial cells [29], immunoblotting of the SVCT2 confirmed the presence of this transporter in A10 cells, making it most likely to account for the transport features observed. 


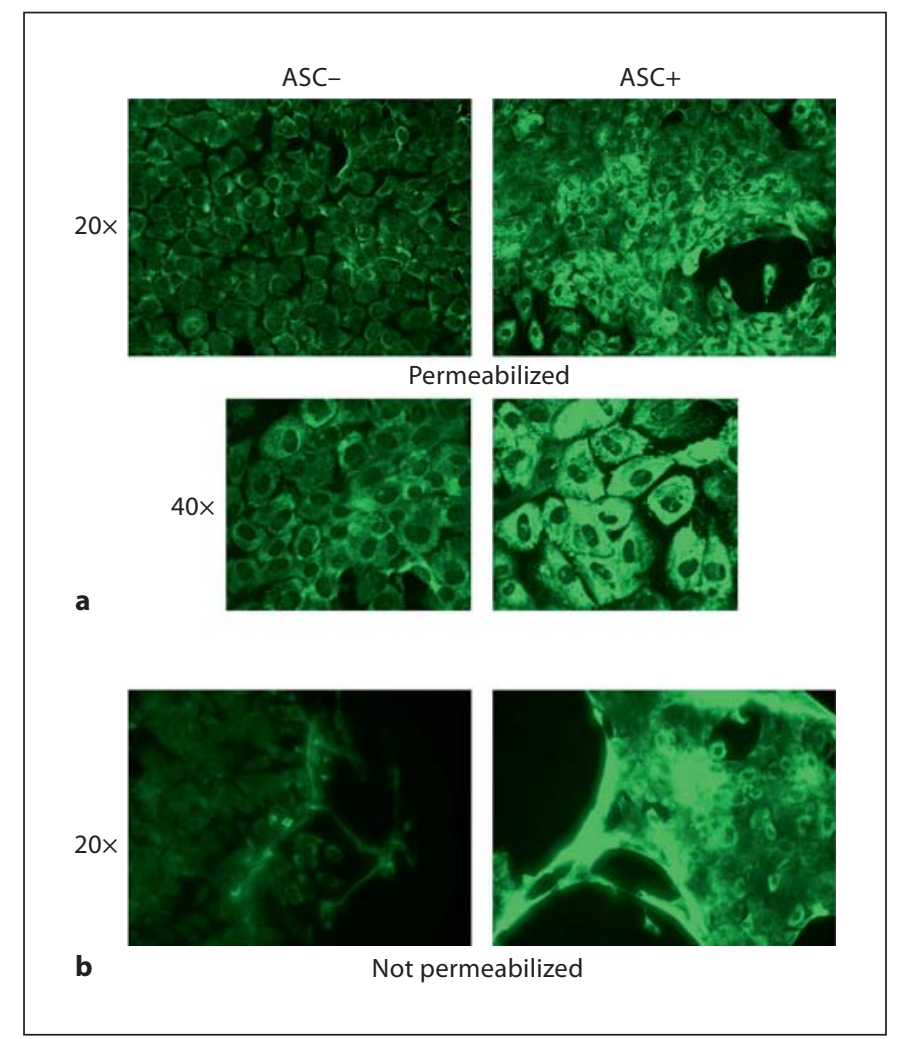

Fig. 9. Ascorbate stimulates type I collagen deposition in immunostains of A10 cells. A10 cells were cultured for 6 days in the absence (column labeled ASC-) or presence of daily additions of $50 \mu \mathrm{M}$ ascorbate (column labeled ASC+) before they were rinsed in $\mathrm{KRH}$ and either permeabilized with $0.3 \%$ Triton X-100 (a, 20× or $40 \times$ magnification) or not permeabilized (b, $20 \times$ magnification) before immunostaining with an antibody that recognizes both $\alpha 1(\mathrm{I})$ and $\alpha 2(\mathrm{I})$ collagen.

A10 cells treated in culture with ascorbate did not show increased proliferation above that due to fetal bovine serum as measured either by thymidine uptake and 5-bromo-2-deoxyuridine labeling. In previous studies, ascorbate effects on cell proliferation were variable, and depended on the ascorbate concentration and on the composition of the extracellular matrix [12, 14, 34]. For example, during cell proliferation, treatment of guinea pig VSMCs with ascorbate concentrations of $0.5 \mathrm{mM}$ and higher inhibited DNA synthesis and growth [14], whereas lower ascorbate concentrations either had no effect (as in the present studies) or showed a modest $25 \%$ stimulation [14]. Thus, although ascorbate enhances VSMC attachment and migration [15], at least at physiologic plasma concentrations, it has little effect on proliferation of VSMCs. This contrasts with endothelial cells, in which similar ascorbate concentrations stimulate cell proliferation $[35,36]$. These differential effects are in line with postulated antiatherosclerotic roles of the vitamin to enhance endothelial cell regeneration and prevent dedifferentiation and subsequent proliferation of VSMCs [19].

As expected, ascorbate enhanced type I collagen generation and maturation in subconfluent A10 cells [19]. More specifically, the major effect of ascorbate was to increase intracellular generation of mature $\alpha 1$ (I) and $\alpha 2$ (I) subunits from the respective procollagen species, which likely reflects ascorbate-stimulated hydroxylation of proline and lysine residues in existing procollagen. A10 cells are typically cultured in medium lacking ascorbate, resulting in a very low to undetectable intracellular ascorbate concentrations. When treated for 16-18 $\mathrm{h}$ with ascorbate at physiologic plasma concentrations $(50-100 \mu \mathrm{M})$, intracellular ascorbate concentrations increased to about $200 \mu \mathrm{M}$. In contrast, generation of mature $\alpha 1$ (I) collagen subtype in A10 cells was maximal at ascorbate loading concentrations of $25 \mu \mathrm{M}$ and even less for the mature $\alpha 2$ (I) subtype. Given that the apparent $\mathrm{K}_{\mathrm{m}}$ of purified prolyl hydroxylase for ascorbate is about $300 \mu \mathrm{M}[11,37]$, the high sensitivity of procollagen maturation induced by ascorbate in A10 cells suggests either that somewhat higher concentrations of ascorbate are present at the enzyme than measured in the whole cell, or that the affinity of the cellular enzyme for ascorbate is increased compared to that of the purified enzyme. The results for type I collagen subtypes in A10 smooth muscle cells contrast with those we previously found for type IV collagen released into the incubation medium by cultured endothelial cells. Maximal release of type IV collagen into the incubation medium of EA.hy926 endothelial cells required intracellular ascorbate concentrations of $2 \mathrm{mM}$ and greater [38]. This difference could relate to the different types of cells and collagen involved, or to the fact that the endothelial cells were confluent and contact-inhibited, whereas the A10 cells in the present study were in the growth phase of culture and were likely synthesizing collagen to allow migration and spreading $[14,15]$. The present results clearly suggest that ascorbate-dependent type I collagen maturation in A10 occurs well within the physiologic plasma range of ascorbate concentrations.

Whereas ascorbate clearly enhanced maturation of type I collagen subunits, its effects on levels of pro $\alpha 1$ (I) collagen were variable. Although most experiments showed an increase in pro $\alpha 1$ (I) collagen with ascorbate treatment (fig. 6-8), some failed to show an increase (e.g., fig. 5). This was likely due to differences in ascorbate-dependent maturation of pro $\alpha 1$ (I) collagen, which would 
deplete it from the cells. A similar explanation could account for the apparent decrease in pro $\alpha 2$ (I) collagen in response to ascorbate. Nonetheless, the overall effect of ascorbate was to stimulate collagen synthesis, evidenced by the modest $30 \%$ increase in proline incorporation into cellular protein observed. These results also agree with a previous study showing that ascorbate increased collagen generation in pig aortic smooth muscle cells by a pretranslational mechanism [10]. Along with the ascorbateinduced increases in intracellular mature $\alpha 1$ (I) and $\alpha 2$ (I) collagen, increased procollagen synthesis contributed to the increased deposition of collagen fibrils observed outside the cells in the present study.

In conclusion, this work documents the role of the SVCT2 transporter in supplying ascorbate for type I collagen synthesis and hydroxylation in A10 VSMCs. It also shows that the predominant effects of ascorbate are to enhance synthesis of proal(I) as well as conversion of both pro $\alpha 1$ (I) and pro $\alpha 2$ (I) collagen subtypes into mature subtypes that can then form stable fibrils required for efficient export from the cell to form the extracellular matrix. Whereas this function of ascorbate on VSMC function is crucial for vascular growth and development, it may also be important in vascular remodeling [8] and stability of collagen [13] in atherosclerotic vessels.

\section{Acknowledgments}

This work was supported by NIH grant DK 050435 and by the Vanderbilt Diabetes Research and Training Center (DK 20593).

\section{References}

1 Ross R: Atherosclerosis - an inflammatory disease. N Engl J Med 1999;340:115-126.

$\checkmark 2$ Reidy MA: Growth factors and arterial smooth muscle cell proliferation. Ann NY Acad Sci 1994;714:225-230.

3 Björkerud B, Björkerud S: Contrary effects of lightly and strongly oxidized LDL with potent promotion of growth versus apoptosis on arterial smooth muscle cells, macrophages, and fibroblasts. Arterioscler Thromb Vasc Biol 1996;16:416-424.

$\checkmark 4$ Desmouliere A, Gabbiani G: The cytoskeleton of arterial smooth muscle cells during human and experimental atheromatosis. Kidney Int Suppl 1992;37:S87-S89.

$\checkmark 5$ Ceconi C, Boraso A, Cargnoni A, Ferrari R Oxidative stress in cardiovascular disease: myth or fact? Arch Biochem Biophys 2003; 420:217-221

6 Tomoda H, Yoshitake M, Morimoto K, Aoki $\mathrm{N}$ : Possible prevention of postangioplasty restenosis by ascorbic acid. Am J Cardiol 1996; 78:1284-1286.

7 Nunes GL, Sgoutas DS, Redden RA, Sigman SR, Gravanis MB, King SB 3rd, Berk BC: Combination of vitamins $\mathrm{C}$ and $\mathrm{E}$ alters the response to coronary balloon injury in the pig. Arterioscler Thromb 1995;15:156-165.

8 Orbe J, Rodriguez JA, Arias R, Belzunce M, Nespereira B, Perez-Ilzarbe M, Roncal C, Paramo JA: Antioxidant vitamins increase the collagen content and reduce MMP-1 in a porcine model of atherosclerosis: implications for plaque stabilization. Atherosclerosis $2003 ; 167: 45-53$. $\checkmark 9$ Barone LM, Faris B, Chipman SD, Toselli P, Oakes BW, Franzblau C: Alteration of the extracellular matrix of smooth muscle cells by ascorbate treatment. Biochim Biophys Acta 1985;840:245-254.

10 Davidson JM, LuValle PA, Zoia O, Quaglino D Jr, Giro M: Ascorbate differentially regulates elastin and collagen biosynthesis in vascular smooth muscle cells and skin fibroblasts by pretranslational mechanisms. J Biol Chem 1997;272:345-352.

11 Tuderman L, Myllylä R, Kivirikko KI: Mechanism of the prolyl hydroxylase reaction. 1. Role of co-substrates. Eur J Biochem 1977;80: 341-348.

12 Schwartz E, Bienkowski RS, Coltoff-Schiller B, Goldfischer S, Blumenfeld OO: Changes in the components of extracellular matrix and in growth properties of cultured aortic smooth muscle cells upon ascorbate feeding. J Cell Biol 1982;92:462-470.

13 Nakata Y, Maeda N: Vulnerable atherosclerotic plaque morphology in apolipoprotein E-deficient mice unable to make ascorbic acid. Circulation 2002;105:1485-1490.

14 Ivanov VO, Ivanova SV, Niedzwiecki A: Ascorbate affects proliferation of guinea-pig vascular smooth muscle cells by direct and extracellular matrix-mediated effects. J Mol Cell Cardiol 1997;29:3293-3303.

15 Rocnik EF, Chan BM, Pickering JG: Evidence for a role of collagen synthesis in arterial smooth muscle cell migration. J Clin Invest 1998;101:1889-1898.
6 Ulrich-Merzenich G, Metzner C, Schiermeyer B, Vetter H: Vitamin C and vitamin E antagonistically modulate human vascular endothelial and smooth muscle cell DNA synthesis and proliferation. Eur J Nutr 2002; 41:27-34.

17 Hornig B, Arakawa N, Kohler C, Drexler H: Vitamin C improves endothelial function of conduit arteries in patients with chronic heart failure. Circulation 1998;97:363-368.

$\checkmark 18$ Arakawa E, Hasegawa K, Yanai N, Obinata M, Matsuda Y: A mouse bone marrow stromal cell line, TBR-B, shows inducible expression of smooth muscle-specific genes. FEBS Lett 2000;481:193-196.

19 Arakawa E, Hasegawa K, Irie J, Ide S, Ushiki J, Yamaguchi K, Oda S, Matsuda Y: L-Ascorbic acid stimulates expression of smooth muscle-specific markers in smooth muscle cells both in vitro and in vivo. J Cardiovasc Pharmacol 2003;42:745-751.

20 Kimes BW, Brandt BL: Characterization of two putative smooth muscle cell lines from rat thoracic aorta. Exp Cell Res 1976;98:349366.

21 Rao RS, Miano JM, Olson EN, Seidel CL: The A10 cell line: a model for neonatal, neointimal, or differentiated vascular smooth muscle cells? Cardiovasc Res 1997;36:118-126.

22 May JM, Qu Z-C, Mendiratta S: Protection and recycling of $\alpha$-tocopherol in human erythrocytes by intracellular ascorbic acid. Arch Biochem Biophys 1998;349:281-289.

23 Hissin PJ, Hilf R: A fluorometric method for determination of oxidized and reduced glutathione in tissues. Anal Biochem 1976;74: 214-226. 
-24 Jones W, Li X, Perriott LM, Whitesell RR, May JM: Uptake, recycling, and antioxidant functions of $\alpha$-lipoic acid in endothelial cells. Free Radic Biol Med 2002;33:83-93.

-25 Totzke G, Metzner C, Ulrich-Merzenich G, Ko Y, Sachinidis A, Vetter H: Effect of vitamin $\mathrm{E}$ and vitamin $\mathrm{C}$ on the DNA synthesis of human umbilical arterial endothelial cells. Eur J Nutr 2001;40:121-126.

-26 Meyer T, Xu L, Chang J, Liu ET, Craven RJ, Cance WG: Breast cancer cell line proliferation blocked by the Src-related Rak tyrosine kinase. Int J Cancer 2003;104:139-146.

27 Laemmli UK: Cleavage of structural proteins during the assembly of the head of bacteriophage T4. Nature 1970;227:680-685.

-28 Due AD, Zhi-Chao Q, Thomas JM, Buchs A, Powers AC, May JM: Role of the C-terminal tail of the GLUT1 glucose transporter in its expression and function in Xenopus laevis oocytes. Biochemistry 1995;34:5462-5471.

29 May JM, Qu ZC: Redox regulation of ascorbic acid transport: role of transporter and intracellular sulfhydryls. Biofactors 2004;20: 199-211.
30 Holmes ME, Samson SE, Wilson JX, Dixon SJ, Grover AK: Ascorbate transport in pig coronary artery smooth muscle: $\mathrm{Na}^{+}$removal and oxidative stress increase loss of accumulated cellular ascorbate. J Vasc Res 2000; 37:390-398

31 Voskoboinik I, Soderholm K, Cotgreave IA: Ascorbate and glutathione homeostasis in vascular smooth muscle cells: cooperation with endothelial cells. Am J Physiol 1998; 275:C1031-C1039.

32 Tsukaguchi H, Tokui T, Mackenzie B, Berger UV, Chen X-Z, Wang YX, Brubaker RF, Hediger MA: A family of mammalian $\mathrm{Na}^{+}$-dependent L-ascorbic acid transporters. Nature 1999;399:70-75

33 Carruthers A, Helgerson AL: Inhibitions of sugar transport produced by ligands binding at opposite sides of the membrane. Evidence for simultaneous occupation of the carrier by maltose and cytochalasin B. Biochemistry 1991;30:3907-3915.
34 Ivanov VO, Rabovsky AB, Ivanova SV, Niedzwiecki A: Transforming growth factor-beta 1 and ascorbate regulate proliferation of cultured smooth muscle cells by independent mechanisms. Atherosclerosis 1998; 140:25-34

35 Schor AM, Schor SL, Allen TD: Effects of culture conditions on the proliferation, morphology and migration of bovine aortic endothelial cells. J Cell Sci 1983;62:267-285.

$>36$ Saeed RW, Peng T, Metz CN: Ascorbic acid blocks the growth inhibitory effect of tumor necrosis factor-alpha on endothelial cells. Exp Biol Med (Maywood) 2003;228:855865.

37 Myllylä R, Tuderman L, Kivirikko KI: Mechanism of the prolyl hydroxylase reaction. 2 . Kinetic analysis of the reaction sequence. Eur J Biochem 1977;80:349-357.

38 May JM, Qu ZC: Transport and intracellular accumulation of vitamin $\mathrm{C}$ in endothelial cells: relevance to collagen synthesis. Arch Biochem Biophys 2005;434:178-186. 